\title{
Effect of Flood Pulse on the Functional Diversity and Traits Composition of Birds With Different Degrees of Wetland Dependence in the Brazilian Pantanal
}

\section{Angélica Vilas Boas da Frota ( $\nabla$ angelicafrotaa@gmail.com )}

Universidade do Estado de Mato Grosso https://orcid.org/0000-0003-3693-4756

\section{Breno Dias Vitorino}

Universidade do Estado de Mato Grosso

Sara Miranda Almeida

Universidade Federal do Para

Josué Ribeiro da Silva Nunes

Universidade do Estado de Mato Grosso

Carolina Joana Da Silva

Universidade do Estado de Mato Grosso

\section{Research Article}

Keywords: Hydrological regimes, Floodplain, Freshwater, Functional richness, Seasonality, Waterbirds

Posted Date: March 17th, 2021

DOl: https://doi.org/10.21203/rs.3.rs-299831/v1

License: (c) (1) This work is licensed under a Creative Commons Attribution 4.0 International License.

Read Full License

Version of Record: A version of this preprint was published at Ornithology Research on July 2nd, 2022. See the published version at https://doi.org/10.1007/s43388-022-00102-4. 
Title: Effect of flood pulse on the functional diversity and traits composition of birds with different degrees of wetland dependence in the Brazilian Pantanal

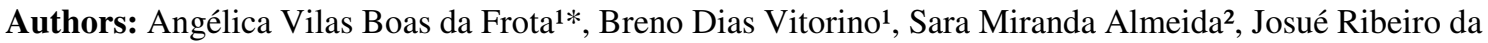

1Programa de Pós-graduação stricto sensu em Ciências Ambientais (PPGCA), Centro de Pesquisa em Limnologia, Biodiversidade e Etnobiologia do Pantanal (CELBE), Universidade do Estado de Mato Grosso (UNEMAT - Cáceres), Cáceres, Mato Grosso, Brasil.

${ }^{2}$ Laboratório de Biogeografia da Conservação e Macroecologia (BIOMACRO Lab), Universidade Federal do Pará (UFPA), Belém, Pará, Brasil.

*Correspondence to: angelicafrotaa@gmail.com

Angélica Vilas Boas da Frota ORCID 0000-0003-3693-4756

Breno Dias Vitorino ORCID 0000-0002-5293-8581

Sara Miranda Almeida ORCID 0000-0002-8372-5482

Carolina Joana da Silva ORCID 0000-0003-0517-1661

Abstract: Hydrological dynamics of the Pantanal wetland drive the availability of resources and niche for aquatic and terrestrial fauna. We consider that changes in the hydrological regime of this floodplain can affect species richness, abundance and functional structure of waterbirds, wetland birds and non-wetland birds. Our study aimed to assess whether the degree of wetland dependence influences the response of bird groups to the flood pulse. We conducted the bird survey in the Paraguay River floodplain system, in five sampling sites, covering the periods of drought, flooding, full flood and ebb of the 2017-2018 hydrological cycle. Species richness and abundance were higher for non-wetland birds than waterbirds and wetland birds. On the other hand, we found that the higher the degree of wetland dependence by birds, the higher the differences in the functional-trait values. Species richness, abundance and all metrics of functional diversity varied significantly when there was an interaction between the degree of wetland dependence and the hydrological period. In all hydrological periods, bird groups occupied distinct niches. Traits such as foraging around or below the water surface were among the dominant functional traits in all hydrological periods. We emphasize the need to consider the functional traits of species in ecological studies of wetlands since measuring only species richness may not reflect the characteristics inherent to this type of ecosystem. In addition, the conservation of wetlands directly implies the maintenance of various niches throughout the hydrological periods, either for dependent or non-dependent bird species in wetlands.

Key words: Hydrological regimes, Floodplain, Freshwater, Functional richness, Seasonality, Waterbirds 


\section{INTRODUCTION}

42

Inland wetlands formed by riverine floodplains are considered one of the most diverse and productive ecosystems in the world (Tockner and Stanford 2002), providing multiple regulating ecosystem services as well as economic and social benefits (Mitsch et al. 2015). Their relevance is recognized by the intergovernmental treaty of the Ramsar Convention (1971), which provides a framework for action to the sustainable use and conservation of wetlands of international importance (Ramsar sites). However, these areas have been widely devastated by human activities and climate change (Gupta et al. 2020), which negatively affects biodiversity in freshwater ecosystems (Albert et al. 2020).

The fluvial system of the Paraguay River in Brazil is one of the main contributors to the largest floodplain in the world, the Pantanal wetland. This system is characterized by annual and pluriannual hydrological regimes of the monomodal type, having a low amplitude and long duration, also known as flood pulse (Junk and Da Silva, 1996). Flood pulses are predictable disturbances that change the dynamics of floodplain communities, enabling the formation of a dynamic, complex and heterogeneous landscape (Junk et al. 1989; Miranda et al. 2018). Changes in hydrological conditions between the terrestrial and aquatic phases, with fluctuations in rainfall and accumulated water level, promote the input, output and lateral interaction of water, nutrients and organisms between rivers or lakes and connected flooded areas (Junk et al. 1989). The different hydrological periods (flooding, full flood, ebb and drought) (Lázaro et al. 2020) are fundamental for the formation of functional units (e.g., central channel, floodplain forest, oxbow lake, pond, swamp) that make up permanent or temporary aquatic habitats (Wantzen et al. 2005) and the various wetland macrohabitat types (Junk et al. 2014) that influence the availability of resources and niche for aquatic and terrestrial fauna (Figueira et al. 2011; de Deus et al. 2020a; de Deus et al. 2020b).

Recently, fires in the Brazilian Pantanal devastated about 30\% of this ecosystem and gained worldwide repercussion due to the magnitude of vegetation devastation, extreme drought and animal deaths in protected and unprotected areas, which also affected the indigenous territories and traditional communities in the region (Libonati et al. 2020; Mega 2020). In addition, the landscape changes caused by "arc of native vegetation loss" at the surrounding floodplain plateau (Guerra et al. 2020), as well as the reduction in water mass and precipitation in recent years, can cause severe changes in biodiversity and ecological functions (Lázaro et al. 2020). Thus, it is imperative to understand the structure and dynamics of biological communities in the Brazilian Pantanal.

Birds play a fundamental role in wetlands by contributing to the flow of matter and energy in the environment and the cycling of nutrients as they have great mobility and participate in a wide range of ecosystem services (Whelan et al. 2008; Green and Elmberg 2013; Luck et al. 2013). Wetland ecosystems such as Pantanal, in turn, provide ideal places for breeding, resting, feeding, and are an important stopover and route for migratory bird species (Somenzari et al. 2018; Jahn et al. 2020). In addition, wetland dependence can drive the turnover of bird species depending on the water level in floodplains (Lorenzón et al. 2020). However, the ecosystem functions of birds in wetlands are often overlooked due to the lack of essential information on their interactions in these environments (Green and Elmberg 2013).

Some studies conducted in the Pantanal demonstrated the importance of environmental heterogeneity and seasonality for the diversity of plants (Catian et al. 2018; Olivo-Neto et al. 2020), 
mammals (Lázari et al. 2013), birds (Deus et al. 2020, Thomas et al. 2020), snakes (Piatti et al. 2019), anurans (Pansonato et al. 2011), fish (Penha et al. 2017) and invertebrates (Aranda and Aoki 2018; Battirola et al. 2018). Nevertheless, due to recurrent environmental changes, there are still gaps in the understanding of events related to seasonality in species diversity (Tonkin et al. 2017). Moreover, knowledge on the ecological role that bird species play in the Pantanal should be explored, as it can support more effective decision-making for the wetland's conservation (Frota et al. 2020b).

Functional diversity measures have been widely used to understand the role of natural processes and environmental disturbance on the structure of biological communities (Mouillot et al. 2013). This approach allows evaluating the organism's response to environmental change, as well as the organism's effect on the functioning of the ecosystem, becoming useful for conservation (Luck et al. 2012). Functional diversity estimates the differences between species or functional groups that coexist in a community based on their functional characteristics (i.e., morphological, physiological and behavioral traits) (Tilman 2001; Petchey and Gaston 2006), determining the impact of biodiversity on the functioning of the ecosystem and the structure of biological communities (Tilman 2004). Although the number of studies approaching functional diversity measures has increased recently, the subject is considered poorly discussed for freshwater environments (Calaça and Grelle 2016). Some studies conducted in aquatic ecosystems demonstrate the strong relationship between functional traits and structural or seasonal environmental characteristics for vertebrates and invertebrates that depend on or are associated with wetlands (Almeida et al. 2016; Cardoso et al. 2017; Almeida et al. 2018; Liu and Wang 2018; Almeida et al. 2019; de Deus et al. 2020b).

In this study, we evaluated whether the degree of wetland dependence influences the response of bird groups (waterbird, wetland bird and non-wetland bird) to the Paraguay River's flood pulse. For this, we tested the hypothesis that the environmental change generated with variations in the water level should cause considerable differences in the composition of bird assemblage over the hydrological cycle, changing species richness, abundance of individuals and their functional structure. We predict that: (1) waterbirds and non-wetland birds are more influenced by the periods of the hydrological cycle, as they have a greater and lesser affinity for wetlands, respectively; (2) the group of waterbirds and wetland birds should have higher values of species richness and abundance of individuals, as well as of diversity of ecological characteristics, in the high-water season (flooding and full flood), whereas non-wetland birds should present greater diversity during low water (ebb and drought); (3) Functional trait composition varies among the three bird groups in each hydrological period, avoiding niche overlap and enabling resource partitioning. Besides that, functional trait proportion also changes between hydrological periods since, in the high waters, birds that feed on items associated with waterbodies should be favored, while in the low waters, nonwetland birds will be favored because there is more availability of resources for land birds.

\section{MATERIAL AND METHODS}

\subsection{Study area}



floodplain of the Pantanal wetland, in the state of Mato Grosso, Paraguay watershed, Brazil (Figure 1). This location includes the Ramsar site Estação Ecológica de Taiamã (EET), a fully protected area by Federal Law n ${ }^{\circ} 9.985 / 2000$, as well as its buffer zone protected by the State Resolution CEPESCA $\mathrm{n}^{\circ} 02 / 2018$, and a Private Reserve of Natural Heritage protected by the same federal legislation. The climate is equatorial savanna with dry winter (Aw) according to the Köppen classification, with an average annual rainfall of $1500 \mathrm{~mm}$ and annual average temperature ranging from $32^{\circ} \mathrm{C}$ to $20^{\circ} \mathrm{C}$ (Kottek et al. 2006). The region's vegetation is classified as Semi-Deciduous Seasonal Alluvial Forest (Veloso et al. 1991).

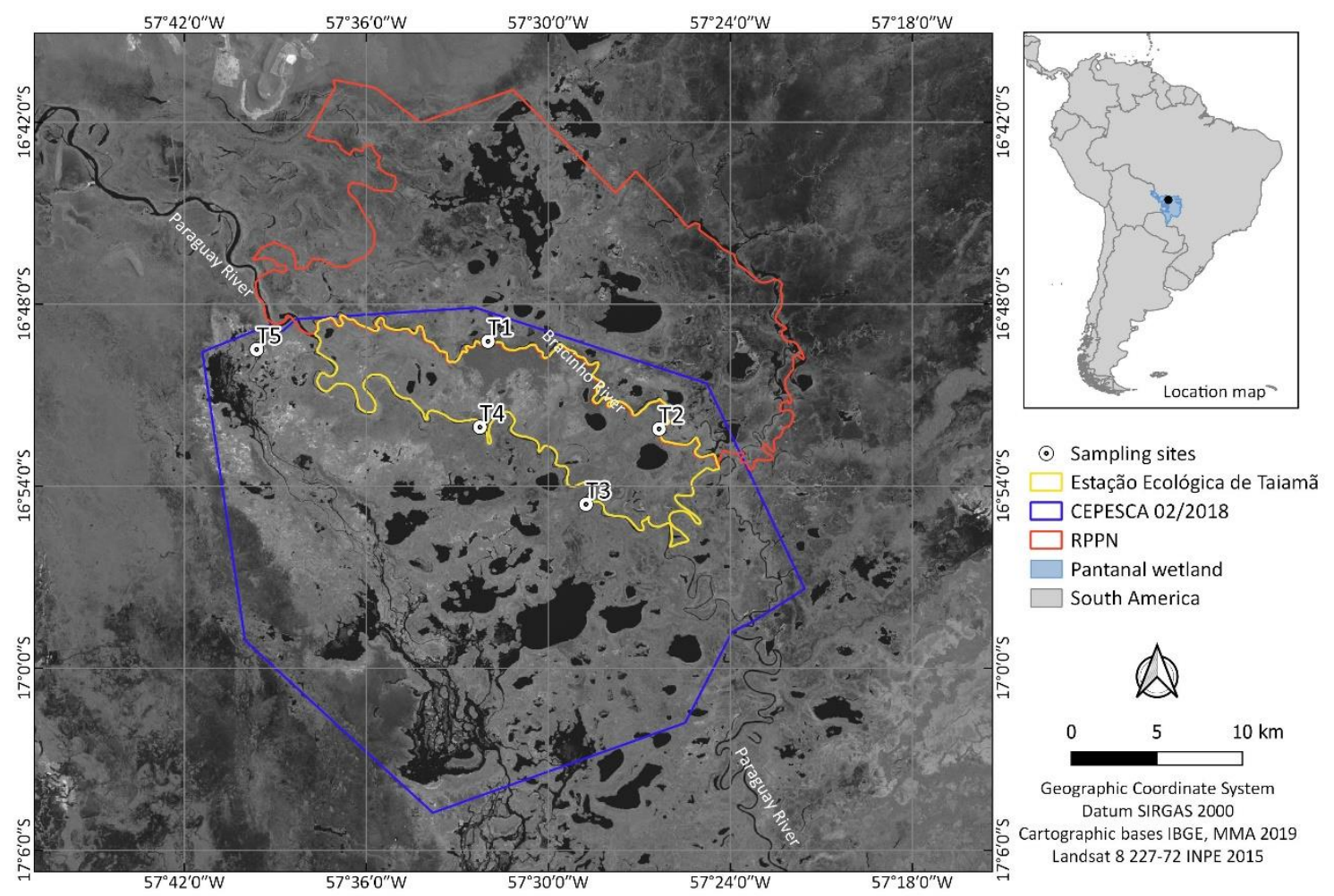

128

Fig. 1 Location of the sampling sites in the Paraguay River floodplain, Pantanal wetland, Brazil.

EET is characterized by different types of wetland macrohabitats consisting predominantly of aquatic areas, such as the channels of the Paraguay and Bracinho rivers, and baías (ponds); swampy areas, such as floating islands and meadows that diversify in their successional stage with various biological forms (e.g., floating, emergent); and aquatic-terrestrial transition zones, which consist of flooded forests and flooded grasslands (Frota et al. 2017). The buffer zone consists of floodplain channels interconnected to irregular depression lakes (Wantzen et al. 2005) and open areas consisting of flooded grasslands and aquatic macrophytes; it also presents patches of flooded forests on the banks of the river channel.

\subsection{Bird survey}

We sampled birds in five areas of the Long-Term Ecological Research site "Dinâmicas Ecológicas na Planície de Inundação do Alto Rio Paraguai" (Figure 1), covering the protected area (EET) and its buffer zone. Sampling was carried out along the river channel and access to the aquatic and terrestrial 

January), full flood (February - April), and ebb (May - July), of the 2017-2018 cycle (Figure 2).

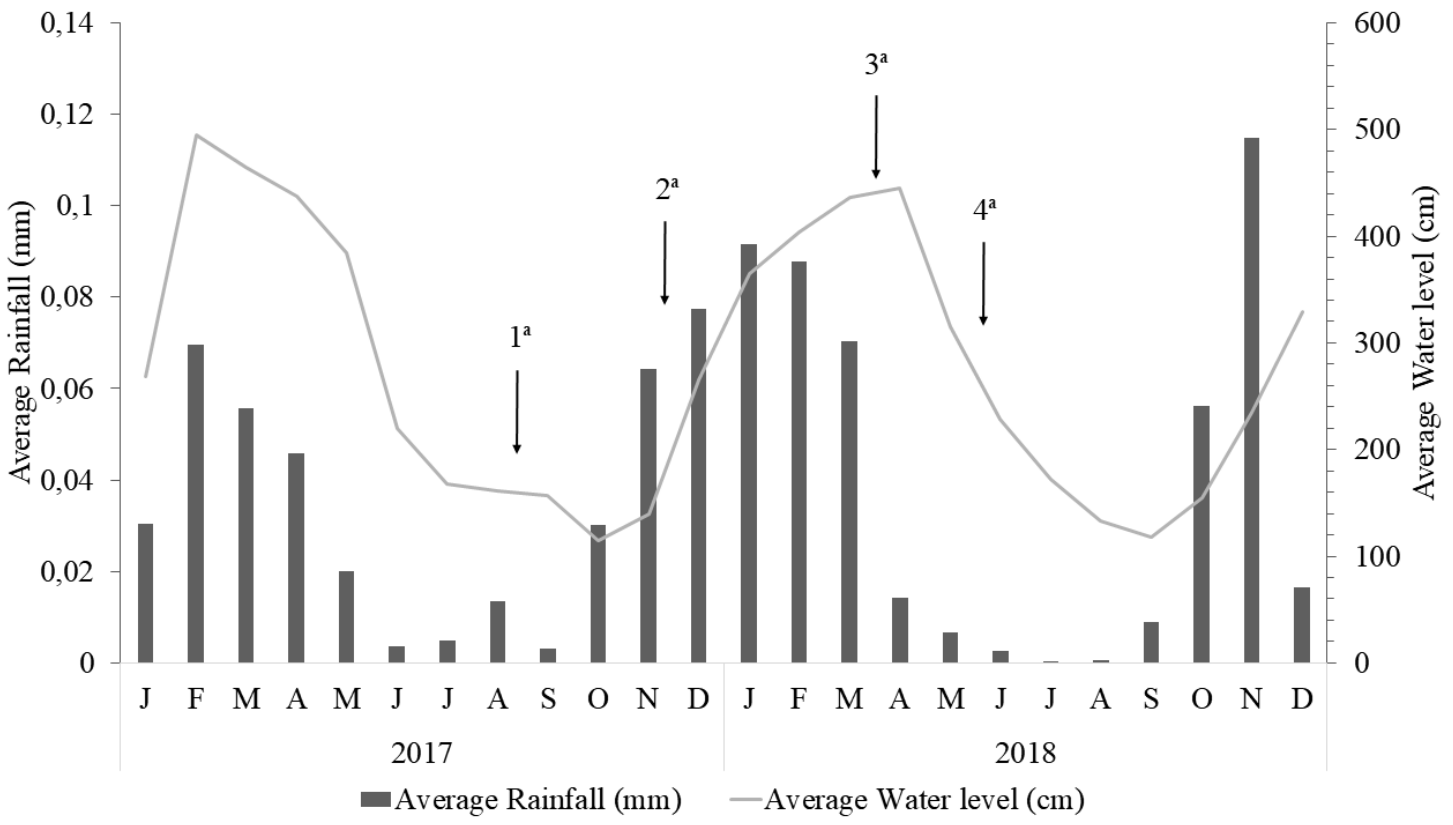

Fig. 2 Hydrological cycle 2017-2018 showing average rainfall (mm) and average water level (cm) in the Paraguay River, Cáceres hydrological station, Paraguay watershed, Brazil. Arrows indicate the four birdmonitoring campaigns carried out during the cycle, covering the hydrological periods drought, flooding, full flood, and ebb. Source of telemetric data: Agência Nacional das Águas (2019).

We established ten point-count stations in each area to sample bird assemblages following the methodology of Blondel et al. (1970). The minimum distance between points was 500 meters to distribute the effort and avoid overlapping records. At each point-count, the bird species and the number of observed and/or heard individuals were recorded for 15 minutes considering a 50-meter radius from the observer. Data collection occurred from 6 am to $10 \mathrm{am}$, with each site being visited for two days in each campaign, totaling a sampling effort of 100 hours of observation.

\subsection{Classification of birds according to the degree of wetland dependence}

For the classification of birds groups, we followed Lorenzón et al. (2020), who categorize birds into three groups according to the degree of wetland dependence: (1) waterbirds, birds that have morphological adaptations to live in aquatic environments; (2) wetland birds, species that depend on resources or habitats in wet systems for food or reproduction; and (3) non-wetland birds, for those associated with terrestrial habitats, such as forest and savanna environments, or generalist habits, but that are not wetland-dependent. For the taxonomic classification of bird species, we followed Piacentini et al. (2015) and, for the migration category, we followed Somenzari et al. (2018).

\subsection{Functional traits}


To measure the functional structure of bird assemblages in relation to hydrological periods and degree of wetlands dependence, we considered 18 functional traits obtained from the EltonTraits database (Wilman et al. 2014), which reflect the use of resources and functional role in natural ecosystems (Luck et al. 2012; Wilman et al. 2014). The functional matrix consisted of 18 traits located in the columns and species in the lines. We used the following functional traits: diet, defined as the proportion of each consumed food item (1 - invertebrates; 2 - endothermic vertebrates, such as mammals and birds; 3 ectothermic vertebrates, such as reptiles and amphibians; 4 - fish; 5 - carrion or carcasses; 6 - vertebrates in general or unknown, when there is no clear identification of what kind of vertebrate was consumed; 7 fruits; 8 - nectar; 9 - seeds; 10 - other plants materials); foraging stratum, treated as the estimated percentage of time spent in each stratum (11 - below water surface; 12 - around water surface; 13 - ground; 14 understory; 15 - mid to high levels of vegetation; 16 - canopy; 17 - aerial); and 18 - biomass (in grams) as a continuous variable.

\subsection{Data analysis}

To understand how bird diversity is influenced by the flood pulse, we calculated for each bird group ("waterbirds", "wetland birds", "non-wetland birds") in each hydrological period (Drought, Flooding, Full Flood, Ebb), species richness and abundance of individuals. We also calculated four complementary functional diversity measures based on the multivariate functional-trait space (Villéger et al. 2008): functional richness (FRic), which represents the functional space filled by the community; functional evenness (FEve), describing the regularity of abundance distribution in the functional space, where values close to zero indicate very irregular functional distances between species and values close to 1 indicate very constant distances; and functional divergence (FDiv), defines how far the abundances of the species are from the center of the functional space (Mason et al. 2005). FDiv values increase if the most abundant species have extreme values of functional characteristics. High functional divergence indicates low niche overlap and low competition between species (Mouchet et al. 2010). We also calculated functional dispersion (FDis), which is the average distance of individual species to the community centroid in a multidimensional characteristics space (Laliberte and Legendre 2010), which is high when niche complementarities increase. Increases in FDis mean that abundances of species with trait values further away from the centroid increased, indicating higher use of the margins of the functional space (Almeida et al. 2019). Also, we calculated community-weighted means (CWM) for each trait of the community. CWM represents the community's functional composition and constitutes average values of the weighted traits at the community level (Lavorel et al. 2008) and enables to assess the association between trait dominance and environmental gradients for an set of communities (Duarte et al. 2018). Functional metrics were calculated considering the three levels of wetland dependence by birds and the four hydrological periods. FRic, FEve, FDiv, FDis and CWM values were calculated using the dbFD function in the FD package of R (Laliberté et al. 2015).

To test differences in species richness, individual abundance and functional diversity between hydrological periods for each bird group, we performed generalized linear mixed models (GLMM) at the sampling-site level. We evaluated isolated effects and interactions between hydrological periods 
(categorical variable with the levels Drought, Flooding, Full Flood and Ebb) and the three groups classified according to the degree of wetland dependence (categorical variable with the levels Waterbirds, Wetland birds, Non-wetland birds). Hydrological period and bird groups were considered in the analyses as fixed factors and sampling site was inserted as a random factor to control the independence of the samples (Zuur et al. 2009). We used Poisson distribution for models evaluating richness and abundance with the link function = "log". For functional diversity measures, we used the Gaussian distribution with the link function = "identity". Model fit was defined using the corrected Akaike Information Criterion (AICc) for small samples, and the best model was the one with the lowest value of AICc. We used the Maximum Likelihood (ML) method to estimate the fitted model values. Null models with no effect were included for comparison. Models were compared using the "F" test for data with normal distribution and the "Chisq" test for nonnormal distribution using a significance level of $5 \%(\mathrm{p} \leq 0.05)$. For these analyses, we used the lme4 package and glmer and lmer functions in R (Bates et al. 2015). Then, for models with significant results, we performed multiple comparisons with Tukey's post-hoc test using the glht function of the multcomp package in R (Hothorn et al. 2008).

To assess which functional traits are the most representative for Waterbirds, Wetland birds and Non-wetland birds in each hydrological period, we performed a Principal Component Analysis (PCA). We calculated the variables' dimensions and evaluated the combined variation of the traits using the cumulative proportion of the two main axes. Values were established according to the average of each trait's community-weighted means (CWM). To verify which variables were the most correlated in each axis, we evaluated the description of the dimensions using the function dimdesc. In this analysis, we used the FactoMineR package (Husson et al. 2007). For graphic design, we use the ggplot2 package (Wickhan et al. 2013). We conducted all statistical analyses in the R environment (R Core Team, 2019).

\section{RESULTS}

\subsection{Overview}

We recorded 15,714 individuals belonging to 162 species, of which 35 are waterbirds $(n=3,425)$, 29 wetland birds $(n=4,147)$ and 98 non-wetland birds $(n=8,142)$. Species were distributed in 21 orders and 48 families (33 non-Passeriformes and 15 Passeriformes). Families with the largest number of species were Tyrannidae (15), Thraupidae (10), Ardeidae (9) and Psittacidae (9). Of the total bird records, 21 are species of total or partial migratory behavior and one species (Crax fasciolata) is in a global threat category (Table 1).

\subsection{Influence of the hydrological period on the diversity of waterbirds, wetland birds and non-} wetland birds

\subsubsection{Waterbirds}

Waterbirds group, showed no diferences in species richness between hydrological periods (Pseudo-F: 3.46; $\mathrm{p}$ = 0.32). There was a difference in abundance between periods (Pseudo-F: 322.76; $\mathrm{p}<$ 
0.001), with the largest number of individuals observed during flooding (mean $=261.4, \mathrm{SD}=278.66$ ) and the smallest during drought (mean $=117$; $\mathrm{SD}=59.81$ ). In the pairwise comparisons, we found similar abundance of waterbirds in the flooding and ebb periods $(\mathrm{p}=0.40)$. On the other hand, flooding presented a larger number of individuals than full flood (mean $=147.2 ; \mathrm{SD}=94.82)$, ebb (mean $=159.4 ; \mathrm{SD}=57.74)$ and drought $($ mean $=117 ; \mathrm{SD}=59.81)$, with significant differences $(\mathrm{p}<0.001$ in all cases $)$. Drought also had a smaller number of individuals than ebb ( $\mathrm{p}<0.001)$ and full flood $(\mathrm{p}<0.001)$.

We found no difference in functional richness between hydrological periods for waterbirds (Pseudo-F: 3.62; $\mathrm{p}=0.30$ ), while full flood had lower FEve (mean = 0.53; SD =0.04) than drought (mean $=0.65 ; \mathrm{SD}=0.06)$ and flooding (mean $=0.65 ; \mathrm{SD}=0.11)($ full flood vs. drought: $\mathrm{p}=0.03$; full flood vs. flooding: $\mathrm{p}=0.02$ ). FDiv was low during the full flood period (mean $=0.66 ; \mathrm{SD}=0.07$ ) when compared to drought $($ mean $=0.83 ; \mathrm{SD}=0.07)(\mathrm{p}<0.001)$. We also observed a decrease in FDiv from the flooding period $($ mean $=0.80 ; \mathrm{SD}=0.05)$ to full flood $(\mathrm{p}=0.008)$ and an increase from the full flood period to ebb $($ mean $=0.83 ; \mathrm{SD}=0.08)(\mathrm{p}<0.001)$. In contrast, FDis values did not vary between hydrological periods for the waterbird assemblage (Pseudo-F: 6.13; $\mathrm{p}=0.10$ ).

\subsubsection{Wetland birds}

Similarly to waterbirds, species richness of wetland birds also did not vary between hydrological periods (Pseudo-F: 1.15; $\mathrm{p}=0.76$ ). Abundance varied in pairwise comparisons of all periods (ebb vs dry, flooding vs dry, flood vs ebb, flooding vs ebb, flooding vs flood, $\mathrm{p}<0.001$ in all cases, Table 2). Although full flood had a higher average abundance of wetland birds (mean $=192.4 ; \mathrm{SD}=91.85)$ than drought (mean $=174.6 ; \mathrm{SD}=24.57)$, this difference was not significant $(\mathrm{p}=0.16)$. As for the functional structure, FRic did not vary between hydrological periods (Pseudo-F: 7.09, p =0.06), and neither did FEve (Pseudo-F: $6.38, \mathrm{p}=0.09$ ) and FDis (Pseudo-F: 6.13, $\mathrm{p}=0.10$ ). There was difference only in FDiv (Pseudo-F: 9.58, $\mathrm{p}$ $=0.02)$, this difference being observed between flooding and drought $(\mathrm{p}=0.04)$ and flooding and flood $(\mathrm{p}$ $=0.02$ ). The lowest value was recorded in flooding (mean $=0.75 ; \mathrm{SD}=0.04$ ) compared to the other two periods.

\subsubsection{Non-wetland birds}

Although species richness of non-wetland birds showed the highest average during the drought period $($ mean $=34.8 ; \mathrm{SD}=10.05)$, we did not find a significant difference between the evaluated periods for this metric (Pseudo-F $=4.38 ; \mathrm{p}=0.22$ ). On the other hand, abundance varied between periods (Pseudo$\mathrm{F}=230.65, \mathrm{p}<0.001)$ being the highest in the drought period (mean $=494.8 ; \mathrm{SD}=225.30)$, while ebb had a higher number of individuals $($ mean $=452.8 ; \mathrm{SD}=163.43)$ than flooding $($ mean $=348.2 ; \mathrm{SD}=78.76)(\mathrm{p}$ $<0.001)$ and full flood (mean = 332.6; SD = 41.91) $(\mathrm{p}<0.001)$. Flooding and full flood, in contrast, did not show difference in abundance for this bird group $(\mathrm{p}=0.538)$. Regarding the functional structure, FRic, FEve and FDiv were similar between periods ( $p=0.91,0.35$ and 0.30 , respectively; Tables 2 and 3 ), while FDis was higher in flooding $($ mean $=0.39 ; \mathrm{SD}=0.02)$ compared to ebb $($ mean $=0.33 ; \mathrm{SD}=0.04 ; \mathrm{p}=0.02)$. 

richness, abundance and the four functional diversity measures varied significantly when there was an interaction of the fixed effects "degree of wetland dependence" and "hydrological period" (Figure 3; Table 4). When assessing the isolated effects, we found that FDiv and FDis did not show significant variation for the degree of wetland dependence, but rather for species richness, abundance, FRic and FEve between bird groups (Table 5). On the other hand, abundance was the only metric that was significantly affected by hydrological period, with differences in the bird assemblages between full flood vs drought ( $z=-6.680 ; p$ $<0.001)$, flooding vs drought $(\mathrm{z}=3.785 ;<0.001)$, full flood vs ebb $(\mathrm{z}=-9.044 ; \mathrm{p}<0.001)$, and flooding vs full flood $(\mathrm{z}=10.435 ;<0.001)$.

Table 4: Comparison of the generalized linear mixed model (GLMM) with the null models, showing the Variance and Standard Deviation (SD) of the random effect "Site", and the degree of freedom (df), test value $\left(\mathrm{X}^{2}\right)$ and the significance level (p-value) of the fixed effects "hydrological period" (drought, flooding, full flood, ebb) and "degree of wetland dependence" (waterbirds, wetland birds, non-wetland birds) on species richness, abundance and functional diversity (FRic, FEve, FDiv and FDis) of birds in the Paraguay River floodplain, Pantanal wetland, Brazil.

\begin{tabular}{|c|c|c|c|c|c|c|c|}
\hline Response variable & Fix Effect & Random & Variance & SD & df & $\mathbf{X}^{2}$ & p value \\
\hline \multirow[t]{4}{*}{ Species Richness } & Group & & & & 2 & 257.89 & $<0.001$ \\
\hline & Period & & & & 3 & 3.31 & 0.34 \\
\hline & Group*Period & & & & 11 & 266.89 & $<0.001$ \\
\hline & & Site & 0.01 & 0.11 & & & \\
\hline \multirow[t]{4}{*}{ Abundance } & Group & & & & 2 & 2335.6 & $<0.001$ \\
\hline & Period & & & & 3 & 127.77 & $<0.001$ \\
\hline & Group*Period & & & & 11 & 2957 & $<0.001$ \\
\hline & & Site & 0.01 & 0.12 & & & \\
\hline \multirow[t]{4}{*}{ FRic } & Group & & & & 2 & 50.27 & $<0.001$ \\
\hline & Period & & & & 3 & 1.34 & 0.71 \\
\hline & Group*Period & & & & 11 & 57.71 & $<0.001$ \\
\hline & & Site & $<0.001$ & 0.01 & & & \\
\hline \multirow[t]{4}{*}{ FEve } & Group & & & & 2 & 14.69 & $<0.001$ \\
\hline & Period & & & & 3 & 2.96 & 0.39 \\
\hline & Group*Period & & & & 11 & 33.72 & $<0.001$ \\
\hline & & Site & $<0.001$ & 0.08 & & & \\
\hline \multirow[t]{4}{*}{ FDiv } & Group & & & & 2 & 0.43 & 0.80 \\
\hline & Period & & & & 3 & 5.05 & 0.16 \\
\hline & Group*Period & & & & 11 & 29.34 & 0.002 \\
\hline & & Site & $<0.001$ & 0.07 & & & \\
\hline \multirow[t]{4}{*}{ FDis } & Group & & & & 3 & 0.37 & 0.82 \\
\hline & Period & & & & 2 & 6.21 & 0.1 \\
\hline & Group*Period & & & & 11 & 38.28 & $<0.001$ \\
\hline & & Site & 0.01 & 0.03 & & & \\
\hline
\end{tabular}



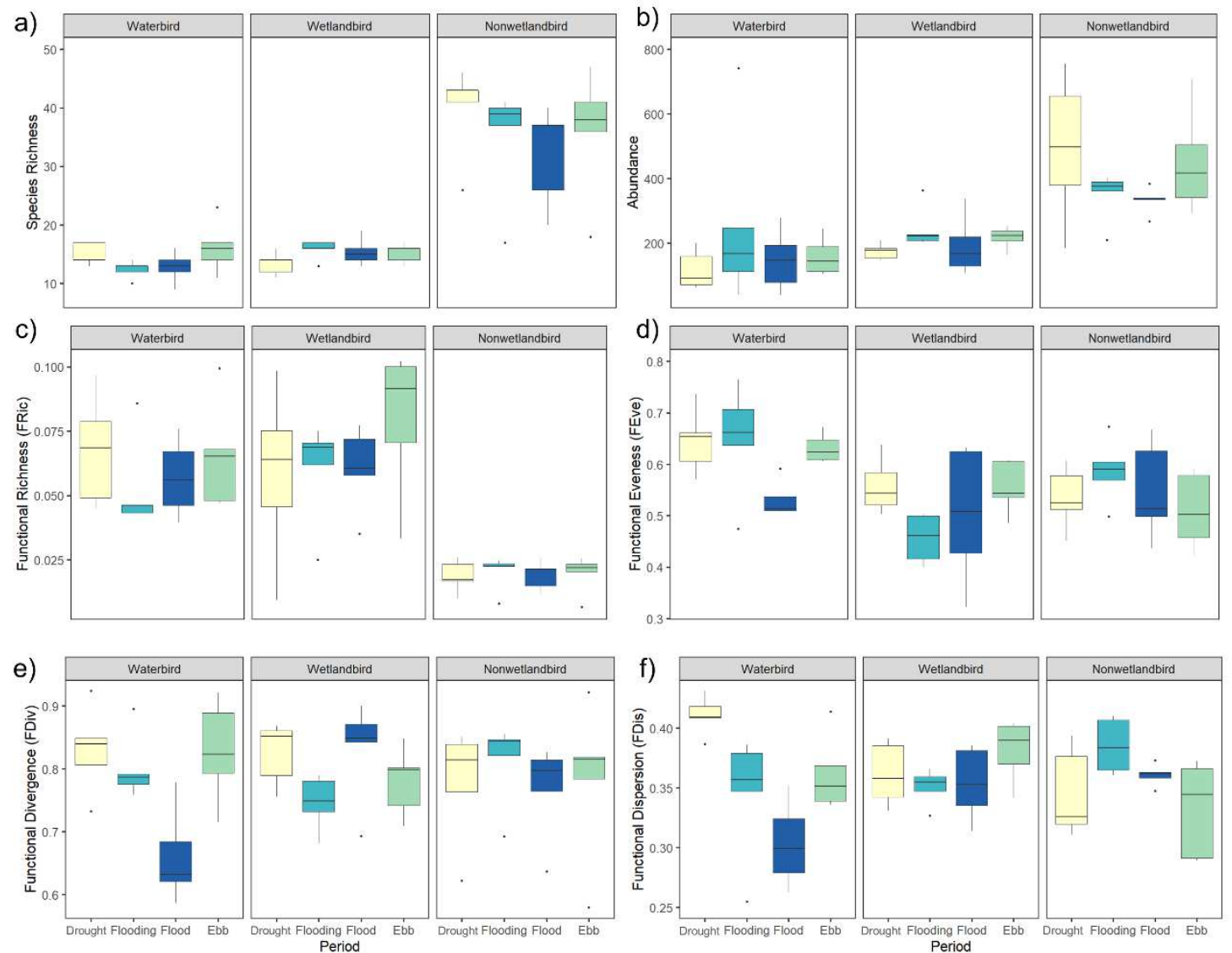

Fig. 3 Variations in species richness, abundance of individuals and functional diversity measures of waterbirds, wetland birds and non-wetland birds between hydrological periods in the Paraguay River floodplain, Pantanal wetland, Brazil. Boxplots show the median values (thick centerline), quartiles (bottom and top of the boxes), maximum and minimum values (whiskers) and outliers (circles). a) Species richness; b) Abundance; c) Functional richness (FRic); d) Functional evenness (FEve); e) Functional divergence (FDiv), f) Functional dispersion (FDis).

\subsection{Functional composition}

The first two PCA axes explained $67.50 \%$ of the variation in the set of functional traits in the drought period. On axis 1 , the most representative traits were foraging around the water surface $\left(R^{2}=0.96\right.$; $\mathrm{p}<0.001)$ and fish diet $\left(\mathrm{R}^{2}=0.84 ; \mathrm{p}<0.001\right)$. On axis 2 , the most representative were invertebrates diet $\left(R^{2}=-0.76 ; p<0.001\right)$ and foraging on the ground $\left(R^{2}=-0.85 ; p<0.001\right)$. In the flooding period, the first two PCA axes explained $68.05 \%$ of the variation in the functional traits, being fish diet $\left(\mathrm{R}^{2}=0.96 ; \mathrm{p}<\right.$ $0.001)$ and foraging around the water surface $\left(\mathrm{R}^{2}=0.89 ; \mathrm{p}<0.001\right)$ the most representative characteristics on axis 1 , and plant diet $\left(R^{2}=-0.65 ; p=0.008\right)$ and foraging on the ground $\left(R^{2}=-0.79 ; p<0.001\right)$ the most representative on axis 2 . In the full flood period, the first two axis explained $70.25 \%$ of the variation in the traits, highlighting foraging around the water surface $\left(\mathrm{R}^{2}=0.95 ; \mathrm{p}<0.001\right)$ and fish diet $\left(\mathrm{R}^{2}=0.94 ; \mathrm{p}<\right.$ $0.001)$ as the most representative on axis 1 . On axis 2 , invertebrate $\operatorname{diet}\left(R^{2}=-0.87 ; p<0.001\right)$ and foraging on the ground $\left(\mathrm{R}^{2}=-0.71 ; \mathrm{p}<0.001\right)$ stood out. In the ebb period, the first two axes explained $66.12 \%$ of the variation, with foraging around the water surface $\left(\mathrm{R}^{2}=0.95 ; \mathrm{p}<0.001\right)$ and diet of ectothermic 
vertebrates $\left(R^{2}=0.89 ; p<0.001\right)$ being the most associated with axis 1 , while invertebrate $\operatorname{diet}\left(R^{2}=0.74\right.$; $\mathrm{p}<0.001)$ and foraging in the aerial stratum $\left(\mathrm{R}^{2}=0.76 ; \mathrm{p}<0.001\right)$ were the most representative on axis 2 .

The ordination diagrams of the principal components generated with CWM values (Figure 4) showed that functional traits such as a diet of fish and ectothermic vertebrates, foraging around the water surface and the weighted average of biomass were positively associated with waterbirds in all hydrological periods. Functional traits of wetland birds seem to be more similar to those of non-wetland birds than those of waterbirds. Invertebrate diet and foraging in the understory were more associated with wetland birds, while fruit diet and foraging in the canopy were more associated with non-wetland birds. This was evidenced mainly in the flooding period when there seemed to be a greater distinction between groups. In the ebb period, however, there was apparently a niche overlap between these two groups regarding a diet of invertebrates and endothermic vertebrates.
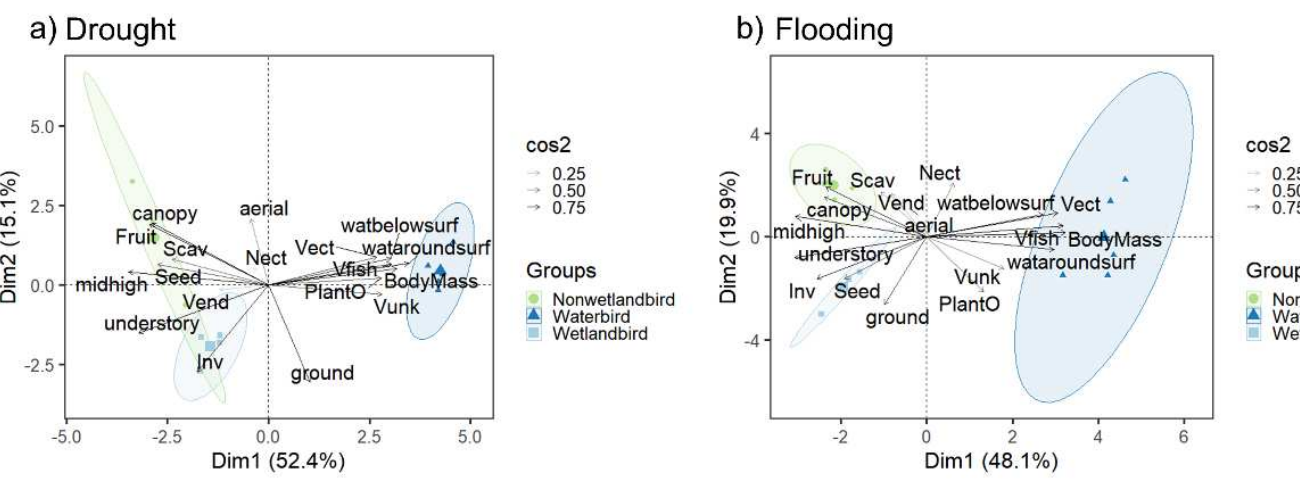

c) Full flood

d) Ebb
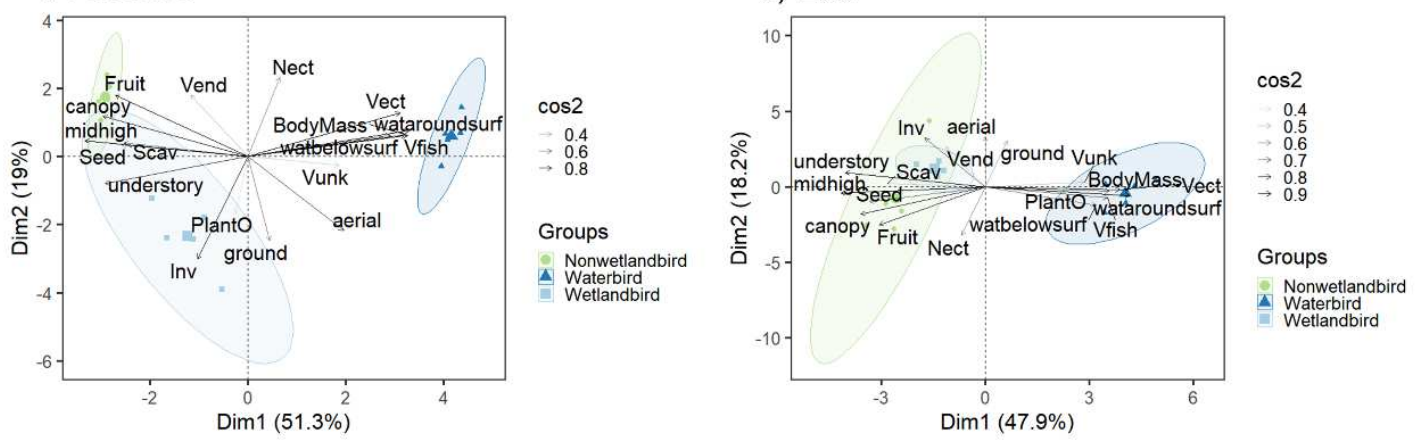

Fig. 4 Ordination diagram of the principal components analysis (PCA) showing the variation in the set of community-weighted mean (CWM) trait value of the waterbirds, wetland birds and non-wetland birds for each hydrological period (a) Drought, b) Flooding, c) Full flood and d) Ebb) in the Paraguay River floodplain, Pantanal wetland, Brazil.

\section{DISCUSSION}

\subsection{Influence of the hydrological period on the diversity of bird groups}

The degree of wetland dependence influenced the birds' response to the flood pulse in the Pantanal wetland. Species richness and abundance of individuals were higher for non-wetland birds than waterbirds and wetland birds, a result similar to that found in another South American river system (Lorenzón et al. 2020). Such results can be attributed to the fact that most neotropical bird species, in general, live in forest 
or non-forest habitats $(\sim 88 \%)$, while a much smaller number $(\sim 12 \%)$ is directly associated with wetlands or aquatic habitats (Stotz et al. 1996).

Flood pulse did not affect species richness and functional richness of the three considered bird groups, revealing that the functional space filled by the bird assemblages remains constant throughout the hydrological periods. The lack of difference in the FRic values suggests that the species within each evaluated group use similar resources throughout the hydrological periods. According to Figueira et al. (2011), factors such as the abundance of different resource types are regulated by environmental heterogeneity and seasonality in the Pantanal, which can allow the coexistence of a larger number of ecologically similar bird species. Similarly, De Deus et al. (2020b) found that the functional diversity of birds was not significantly affected by seasonality in the northern Pantanal, but habitat type (forest $\mathrm{x}$ savanna) had a strong influence on structure and functional diversity.

The abundance of individuals varied between the hydrological periods for the three groups, and we found that waterbirds showed the highest abundance values during flooding and the lowest in the drought period. On the other hand, non-wetland birds predominated during ebb and drought, and were less abundant in flooding and full flood, corroborating our initial hypothesis. This agrees with the study of Lorenzón et al. (2020), which also found higher abundance values for non-wetland birds during the lowwater period.

Waterbird FEve was low during full flood, showing that during this period the functional distances were less regular, which indicates that some parts of the niche, even if occupied, are underutilized (Villéger et al. 2008; Almeida et al. 2016). FEve did not vary for wetlandbirds or non-wetland birds between the evaluated periods, indicating that the functional distribution of these bird groups remains throughout the hydrological cycle.

FDiv varied between periods considering waterbirds, being lower during the full flood period than during drought. We also noticed an FDiv decrease in the flooding period in relation to full flood and an increase in the period of full flood in relation to ebb. Such results reveal that there is a low niche differentiation between species in the assemblage during the high-water period, as the most abundant species are ecologically very similar and can compete for resources (Mason et al. 2005; Mouchet et al. 2010). This may also reflect the reduced niche availability during the flood season, favoring species that are adapted to these conditions, such as birds of the Family Ardeidae, which can forage among wetlands connected to river channels. For wetland birds, the lowest FDiv value was observed in the flooding period compared to drought and full flood, evidencing a low degree of niche differentiation among species during flooding, which can cause greater resource competition during this period. This measure did not vary for non-wetland birds possibly because they took refuge in non-flooding environments, use resources in higher strata of vegetation, or even because of behavioral factors such as migration. According to Pinho et al. (2017), some birds can have seasonal or occasional movements looking for better conditions and greater availability of resources throughout the year.

Functional dispersion of the waterbirds was greater during drought when compared to flooding and full flood, suggesting that there are more complementary niches in this period (Laliberte and Legendre 2010). In turn, FDis did not vary between the hydrological periods for the wetland bird assemblage, while non-wetland birds showed higher FDis in flooding compared to ebb, which indicates greater niche 
complementarity during flooding (Laliberte and Legendre 2010). In general, a previous study observed that the bird community was functionally overdispersed throughout the seasons in flooded areas (de Deus et al. 2020b). However, in the present study, we found that there is a variation in the functional dispersion for bird groups considering their degree of wetland dependence.

Our results showed that the fluctuation from different hydrological periods combined with the degree of wetlands dependence by species influences the richness, abundance and functional diversity of birds in the Pantanal. The isolated effect of hydrological periods on bird assemblages influenced only abundance. However, when assessing the combined effect of period and different bird groups, significant differences were observed for all considered diversity measures. This result indicates that evaluating only the general species assemblage can mask important wetland-dependent responses of birds, as observed for forest-dependent birds (Matuoka et al. 2020). This is so because birds in wetlands can be affected differently by disturbances due to their response to water level (Lorenzón et al. 2020) throughout the seasons (Che et al. 2019), as well as regarding the wetland type, degree of environmental conservation (Almeida et al. 2020) and degree of connectivity of the water-bodies (Almeida et al. 2016). Still, biotic factors such as functional characteristics can be considered the main determinants of ecosystem processes, regardless of the hydrological regime (Setubal et al. 2020).

In general, we observed that birds with a higher degree of wetland dependence (waterbirds and wetland birds) showed greater differences in trait values (i.e., functional richness) in the Paraguay River floodplain compared to non-wetland birds (Figure 3; Table 5). In contrast, species richness and abundance of non-wetland birds showed higher values compared to the two other groups (Figure 3). Diversity measures with this inverse response reveal that a larger number of non-wetland birds have similar characteristics. It is noteworthy that less diverse but abundant resources in environments with different annual hydrological regimes can enable increased efficiency of resource exploitation by most species with similar ecological characteristics (Setubal et al. 2020). In addition, this variation demonstrates the relevance of natural wetland ecosystems toward maintaining the diversity of ecological functions.

\subsection{Trait composition}

Changes in the trait composition between hydrological periods were observed for wetland birds and non-wetland birds. Bird composition usually varies depending on the available macrohabitat types in each hydrological period (Frota et al. 2020a). Our result also highlights the importance of the flood pulse for the maintenance of the functional role of these birds, here demonstrated by the functional composition based on dominant traits of bird assemblages. We evaluated a river system that harbor mostly of nonpasserine species, which can directly contribute to a greater variety of functional traits due to the evolutionary distance of these organisms, which can or can not share ecological characteristics.

Waterbirds presented a distinct ecological niche in relation to wetland and non-wetland birds in the four evaluated hydrological periods. The most characteristic traits of waterbirds were food items obtained in the aquatic environment (e.g., fish) and foraging around or below the water surface, which was already expected, considering their adaptations to aquatic habitats or aquatic-terrestrial transition zones. Also, we highlight that these traits were predominant even in the drought and ebb periods possibly due to 
the predominance of permanent aquatic habitats, such as swamps and marshes, in this floodplain sector (Wantzen et al. 2005; Frota et al. 2017).

Waterbirds (e.g., Ciconiiformes, Pelecaniformes) are organisms with high mobility and biomass, so they require a large amount of energy, which can be provided via the consumption of fish. The relationship between aquatic birds and the fish fauna in the Pantanal seems to be little studied (Keppeler et al. 2016), even though they are important regulators of these taxa in freshwater ecosystems, especially in the flooding and full flood periods, which were the periods in which we detected the highest abundance of waterbirds, corroborating the study of Kantek et al. (2020). These periods coincide with the "dequada" process in the region, which occurs due to limnological changes, such as the depletion of dissolved oxygen in the aquatic system, and causes greater vulnerability and mortality of fish (Oliveira et al. 2013) and, consequently, enables a high food supply for piscivorous birds or those that occasionally feed on fish.

Waterbirds also showed a dominance of plants materials in their diet. We highlight here that some waterbird species can be important vectors of endozoochory (Wilkinson et al. 2017; Lovas-Kiss et al. 2020) not only secondarily but also primarily (Van Leeuwen et al. 2017). This group can disperse viable seeds or plant propagules over long distances (Kleyheeg et al. 2019). Dispersion by waterbirds can depend on species and season, being of fundamental importance for aquatic, amphibious and terrestrial plants to connect to wetlands at different scales (Silva et al. 2020).

In floodplains, forests and grasslands are essential to ensure plant resources such as fruits, seeds and flowers for species associated with these traits in their diet, as observed for wetland birds and nonwetland birds. Resource maintenance for these bird groups often generates an interdependent relationship, through mutualistic interactions. Such interactions can highlight the role played by these birds in the seed dispersal and pollination processes, enabling the plant species recruitment and colonization of new areas (García 2016). This is especially importante for plants that are more tolerant to flooding and that establish themselves in environments with greater sediment deposition during the alternation of aquatic and terrestrial phases of the hydrological cycle. Among these plants, we can mention the trees Erythrina fusca Lour. (Fabaceae) and Calophyllum brasiliense Cambess (Calophyllaceae) (Olivo-Neto et al. 2020) that are commonly observed in the area of the presente study.

In general, bird groups occupied distinct niches in all hydrological periods. We observed that wetland birds and non-wetland birds share some traits such as invertebrate and endothermic vertebrate diet in the ebb period. During flooding and full flood, non-wetland birds were more restricted to the highest strata of vegetation. Still, foraging on the ground showed a strong negative relationship in these periods, which reveals that, when the water level is high, the foraging in this stratum decreases. During ebb and drought, foraging on mid to high levels of vegetation and in the understory was also associated with the non-wetland group, thus favoring the exploitation of a greater variety of resources in more structured environments such as forests. According to de Deus et al. (2020b), forest areas, in contrast to savannas, may have a larger number of potential niches and allow a greater co-occurrence of species.

Insectivorous birds are highly diverse in tropical ecosystems and have important coexistence mechanisms (Sherry et al. 2020). This is a possible explanation for the predominance of the invertebrate diet found in our results, which was mainly associated with wetland birds and non-wetland birds in all hydrological periods. We emphasize that birds with this diet trait play an important regulatory role in 
controlling insect populations and reducing plant damage, and the loss of this functional group can lead to negative consequences in trophic cascades (Sekercioglu et al. 2004).

\subsection{Threats to bird diversity in natural wetlands}

The conservation status of wetland-dependent species has decreased at higher rates than that of species associated with other ecosystems (Davidson 2016) and the goal of the Ramsar Convention to contain wetland degradation has not been achieved yet (Davidson et al. 2019). Although freshwater wetlands play a major role in maintaining ecosystem services (Mitsch et al. 2015), these are considered "exploitable" areas and are, consequently, highly threatened. Studies show that wetlands and biodiversity in freshwater ecosystems are much more threatened than marine and terrestrial ecosystems, due to emerging threats such as use of natural resources, climate change and contamination by microplastics and biochemicals (Reid et al. 2019).

In the Pantanal wetland, loss of water mass in the past 10 years has already been observed due to climate changes aggravated by anthropogenic pressures (Lázaro et al. 2020), and the reduction of these floodplains can drive the loss of the functional diversity of waterbirds and wetland-dependent birds. These conditions occur due to the impact of the agricultural and energy sectors in the ecological system of the Pantanal. Agriculture, represented by land use, generates pressures such as the conversion of natural ecosystems and the loss of macrohabitats and biodiversity. Energy, represented by the hydroelectric power production matrix, which is characterized by many large (UHs) and small hydroelectric plants (PCHs) in the Upper Paraguay basin, affects longitudinal and lateral hydrological connectivity (Da Silva et al. 2015). Human pressure established in natural ecosystems, such as the loss of native vegetation (i.e., deforestation, burning), degradation of water quality, modification in the hydrology patterns, and draining of wetlands (Gupta et al. 2020), is the cause of an ongoing decline in avian diversity due to habitat loss and also affects ecological functions (Sekercioglu et al. 2004; Sekercioglu 2006; Sekercioglu 2012).

\subsection{Conclusion and implications for conservation}

In our study, we accessed bird diversity and functional structure in the Brazilian Pantanal considering the degree of wetland dependence by avian groups. We emphasize the need to evaluate functional metrics in ecological studies of the region and in assessments of environmental impact on wetlands since measuring only species richness may not reflect the characteristics inherent to this ecosystem type. In this way, it is also possible to assess more effectively the conservation status of wetland ecosystems. The results presented here provide subsidies to encourage decision-making for environmental policies in the Paraguay River floodplain and other lowland river systems.

Furthermore, wetland conservation directly implies the maintenance of different niches throughout hydrological periods, whether for species that are dependent or not on wetlands. The loss of important functional groups can result in greatly modified ecological communities regarding structure and function (Norris et al. 2020). Moreover, integrated terrestrial-freshwater planning can guarantee benefits for the aquatic biodiversity without losses on the terrestrial biodiversity (Leal et al. 2020). 


\section{Funding}

522 Coordenação de Aperfeiçoamento de Pessoal de Nível Superior (CAPES) and Fundação de Amparo à

523 Pesquisa do Estado de Mato Grosso (FAPEMAT) for scholarship granted to AVBF and BDV; Conselho

524 Nacional de Desenvolvimento Científico e Tecnológico (CNPq) for research fellowship to CJS; and CNPq

525 for funding in Long-Term Ecological Research (LTER) "Ecological Dynamics of the Upper Paraguay

526 River" (no. 441563/2016-3).

527

\section{Conflicts of interest/Competing interests}

529 There are no conflicts of interests.

530

531

\section{Availability of data and material}

532 The datasets used and/or analysed during the current study are available from the corresponding author on reasonable request.

534

535

\section{Code availability}

536

Not applicable

537

538

\section{Authors' contributions}

539 Conceptualization: AVBF and BDV; Methodology and Investigation: AVBF, BDV and SMA; Data 540 curation and analyses: AVBF; Writing - original draft: AVBF; Writing - review and editing: AVBF, BDV, SMA, JRSN and CJS. All authors revised and approved the final version this manuscript.

542

\section{Ethics Approval}

544 This study follows the license from the responsible authority for carrying out the research in the respective

545 area. The permission activities with a scientific purpose are under authorization number 59399 of

546 Biodiversity Authorization and Information System - SISBIO/ICMBio.

\section{Acknowledgements:}

550 This study was financed in part by the Coordenação de Aperfeiçoamento de Pessoal de Nivel Superior -

551 Brazil (CAPES) - Finace Code 001, the Conselho Nacional de Desenvolvimento Científico e Tecnológico 552 (CNPq) and Fundação de Amparo à Pesquisa do Estado de Mato Grosso (FAPEMAT): AVBF and BDV 553 received a scholarship from FAPEMAT / CAPES 007/2018; and CJS received a research fellowship from 554 CNPq; We also thank CNPq for support in Long-Term Ecological Research (LTER) Pantanal "Ecological 555 Dynamics of the Upper Paraguay River" (no. 441563/2016-3), contribution number 6 for this Project; to 556 the Programa de Pós-graduação em Ciências Ambientais of Universidade do Estado de Mato Grosso, 557 Cáceres, the Centro de Pesquisa em Limnologia, Biodiversidade e Etnobiologia do Pantanal (CELBE) and 
Instituto Chico Mendes de Conservação da Biodiversidade, Estação Ecológica de Taiamã (ICMBio/EET) for financial and logistical support.

\section{REFERENCES}

Albert JS, Destouni G, Duke-Sylvester SM, Magurran AE, Oberdorff T, Reis RE, Winemiller KO, Ripple WJ (2020) Scientists' warning to humanity on the freshwater biodiversity crisis. Ambio. https://doi.org/10.1007/s13280-020-01318-8

Almeida B de A, Gimenes MR, dos Anjos L (2016) Wading bird functional diversity in a floodplain: Influence of habitat type and hydrological cycle. Austral Ecol 42:84-93 . https://doi.org/10.1111/aec.12403

Almeida B de A, Green AJ, Sebastián-González E, dos Anjos L (2018) Comparing species richness, functional diversity and functional composition of waterbird communities along environmental gradients in the neotropics. PLoS One 13:1-18 . https://doi.org/10.1371/journal.pone.0200959

Almeida B de A, Sebastián-González E, Anjos L dos, Green AJ, Botella F (2019) A functional perspective for breeding and wintering waterbird communities: temporal trends in species and trait diversity. Oikos 1-13 . https://doi.org/10.1111/oik.05903

Almeida B de A, Sebastián-González E, dos Anjos L, Green AJ (2020) Comparing the diversity and composition of waterbird functional traits between natural , restored , and artificial wetlands. Freshw Biol 1-15 . https://doi.org/10.1111/fwb.13618

Aranda R, Aoki C (2018) Diversity and effect of historical inundation on bee and wasp (Hymenoptera: Apoidea, Vespoidea) communities in the Brazilian Pantanal. J Insect Conserv 22:581-591 . https://doi.org/10.1007/s10841-018-0087-3

Bates D, Mächler M, Bolker BM, Walker SC (2015) Fitting linear mixed-effects models using lme4. J Stat Softw 67: . https://doi.org/10.18637/jss.v067.i01

Battirola LD, Golovatch SI, Pinheiro TG, Batistella DA, Rosado-Neto GH, Chagas A, Brescovit AD, Marques MI (2018) Myriapod (Arthropoda, Myriapoda) diversity and distribution in a floodplain forest of the Brazilian Pantanal. Stud Neotrop Fauna Environ 53:62-74. https://doi.org/10.1080/01650521.2017.1397978

Blondel J, Ferry C, Frochot B (1970) La méthod des indices ponctuels d'abundance (IPA) ou des relevés d'avifaune par "stations d'écoute". Alauda 38:55-71.

Calaça AM, Grelle CEV (2016) Diversidade funcional de comunidades: Discussões conceituais e importantes avanços metodológicos. Oecologia Aust 20:401-416 . https://doi.org/10.4257/oeco.2016.2004.01

Cardoso SJ, Nabout JC, Farjalla VF, Lopes PM, Bozelli RL, Huszar VLM, Roland F (2017) Environmental factors driving phytoplankton taxonomic and functional diversity in Amazonian floodplain lakes. Hydrobiologia 802:115-130 . https://doi.org/10.1007/s10750-017-3244-x

Catian G, da Silva DM, Súarez YR, Scremin-Dias E (2018) Effects of Flood Pulse Dynamics on Functional Diversity of Macrophyte Communities in the Pantanal Wetland. Wetlands 1-17 . https://doi.org/10.1007/s13157-018-1050-5 
Che X, Chen D, Zhang M, Quan Q, Møller AP, Zou F (2019) Seasonal dynamics of waterbird assembly mechanisms revealed by patterns in phylogenetic and functional diversity in a subtropical wetland. Biotropica 51:421-431 . https://doi.org/10.1111/btp.12648

Da Silva CJ, Silva Sousa KN, Ikeda-Castrillon SK, Lopes CRAS, da Silva Nunes JR, Carniello MA, Mariotti PR, Lazaro WL, Morini A, Zago BW, Façanha CL, Albernaz-Silveira R, Loureiro E, Viana IG, Oliveira RF de, Alves da Cruz WJ, de Arruda JC, Sander NL, de Freitas Junior DS, Pinto VR, de Lima AC, Jongman RHG (2015) Biodiversity and its drivers and pressures of change in the wetlands of the Upper Paraguay-Guaporé Ecotone, Mato Grosso (Brazil). Land use policy 47:163178 . https://doi.org/10.1016/j.landusepol.2015.04.004

Davidson NC (2016) Wetland Losses and the Status of Wetland-Dependent Species. In: Finlayson C., Milton G., Prentice R. DN (ed) The Wetland Book. Springer, Dordrecht, pp 1-14

Davidson NC, Dinesen L, Fennessy S, Finlayson CM, Grillas P, Grobicki A, McInnes RJ, Stroud DA (2019) Trends in the ecological character of the world's wetlands. Mar Freshw Res 71:127-138 . https://doi.org/10.1071/MF18329

de Deus FF, Schuchmann K-L, Arieira J, de Oliveira Tissiani AS, Marques MI (2020a) Avian Beta Diversity in a Neotropical Wetland: the Effects of Flooding and Vegetation Structure. Wetlands. https://doi.org/10.1007/s13157-019-01240-0

de Deus FF, Schuchmann K-L, Marques MI (2020b) Seasonality in the Brazilian Pantanal influences avian functional diversity. Stud Neotrop Fauna Environ 1-11

Duarte LDS, Debastiani VJ, Carlucci MB, Diniz-Filho JAF (2018) Analyzing community-weighted trait means across environmental gradients: should phylogeny stay or should it go? Ecology 99:385-398 . https://doi.org/10.1002/ecy.2081

Figueira JEC, Mourão FA, Coelho AS (2011) Habitat heterogeneity and climatic seasonality structure the avifauna trophic guilds in the Brazilian Pantanal wetland. Can J Zool 89:1206-1213 . https://doi.org/10.1139/z11-099

Frota AVB da, Ikeda-castrillon SK, Kantek DLZ, Da Silva CJ (2017) Macrohabitats da Estação Ecológica de Taiamã, no contexto da Área Úmida Pantanal mato-grossense, Brasil. Bol Mus Para Emílio Goeldi Cienc Nat 12:239-254

Frota AVB da, Vitorino BD, da Silva CJ, Ikeda-Castrillon SK, Nunes JR da S (2020a) Bird community structure in macrohabitats of the aquatic-terrestrial transition zone in the Pantanal wetland, Brazil. Oecologia Aust 24:615-634

Frota AVB da, Vitorino BD, Nunes JR da S, da Silva CJ (2020b) Main trends and gaps in studies for bird conservation in the Pantanal wetland. Neotrop Biol Conserv 15:427-445 . https://doi.org/10.3897/neotropical.15.e52905

García D (2016) Birds in ecological networks: Insights from bird-plant mutualistic interactions. Ardeola 63:5-34 . https://doi.org/10.13157/arla.63.1.2016.rp7

Green AJ, Elmberg J (2013) Ecosystem services provided by waterbirds. Biol Rev. https://doi.org/10.1111/brv.12045

Guerra A, Roque F de O, Garcia LC, Ochao-Quintero JMO, Oliveira PTS de, Guariento RD, Rosa IMD (2020) Drivers and projections of vegetation loss in the Pantanal and surrounding ecosystems. Land 
use policy 91: . https://doi.org/10.1016/j.landusepol.2019.104388

Gupta G, Khan J, Upadhyay AK, Singh NK (2020) Wetland as a Sustainable Reservoir of Ecosystem Services: Prospects of Threat and Conservation. Restor Wetl Ecosyst A Trajectory Towar a Sustain Environ 31-43 . https://doi.org/10.1007/978-981-13-7665-8_3

Hothorn T, Bretz F, Westfall P (2008). Simultaneous Inference in General Parametric Models. Biometrical Journal 50(3): 346-363. 10.1002/bimj.200810425.

Husson F, Josse J, Lê S, Mazet J (2007). FactoMineR: Factor Analysis and Data Mining with R. R package version 1.04, URLhttp://CRAN.R-project.org/package=FactoMineR.

Jahn AE, Cueto VR, Fontana CS, Guaraldo AC, Levey DJ, Marra PP, Ryder TB (2020) Bird migration within the Neotropics. Auk 137:1-23 . https://doi.org/10.1093/auk/ukaa033

Junk WJ, Bayley PB, Sparks RE (1989) The Flood Pulse Concept in River-Floodplain Systems. Can Spec Publ Fish Aquat Sci 106:110-127 . https://doi.org/citeulike-article-id:3662134

Junk WJ, Da Silva CJ (1996) O conceito do Pulso de Inundação e suas implicações para o Pantanal de Mato Grosso. Anais do Simpósio sobre Recursos Naturais e Socioeconômicos do Pantanal: Manejo e Conservação 2: 17-28.

Junk WJ, Piedade MTF, Lourival R, Wittmann F, Kandus P, Lacerda LD, Bozelli RL, Esteves FA, Nunes da Cunha C, Maltchik L, Schöngart J, Schaeffer-Novelli Y, Agostinho AA (2014) Brazilian wetlands: Their definition, delineation, and classification for research, sustainable management, and protection. Aquat Conserv Mar Freshw Ecosyst 24:5-22 . https://doi.org/10.1002/aqc.2386

Kantek DLZ, Melo RC De, Miyazaki SS, Castilheiro WFF, Santos-Filho M dos (2020) Aquatic Birds at the Taiamã Ecological Station : Seasonal Variation of Community Structure and the Importance of Protected Areas in the Pantanal The Pantanal biome, which is the largest. Biodiversidade Bras 10:24-40 . https://doi.org/10.37002/biobrasil.v10i3.1513

Keppeler FW, Cruz DA, Dalponti G, Mormul RP (2016) The role of deterministic factors and stochasticity on the trophic interactions between birds and fish in temporary floodplain ponds. Hydrobiologia 773:225-240 . https://doi.org/10.1007/s10750-016-2705-y

Kleyheeg E, Fiedler W, Safi K, Waldenström J, Wikelski M, van Toor ML (2019) A comprehensive model for the quantitative estimation of seed dispersal by migratory mallards. Front Ecol Evol 7:114 . https://doi.org/10.3389/fevo.2019.00040

Kottek M, Grieser J, Beck C, Rudolf B, Rubel F (2006) World Map of the Köppen-Geiger climate classification updated. Meteorol Zeitschrift 15:259-263 . https://doi.org/10.1127/09412948/2006/0130

Laliberte E, Legendre P (2010) A distance-based framework for measuring functional diversity from multiple traits. Ecology 91:299-305 . https://doi.org/10.1890/08-2244.1

Laliberté E, Legendre P, Shipley B (2015) FD: measuring functional diversity from multiple traits, and other tools for functional ecology. R Packag Version 1.0-12

Lavorel S, Grigulis K, McIntyre S, Williams NSG, Garden D, Dorrough J, Berman S, Quétier F, Thébault A, Bonis A (2008) Assessing functional diversity in the field - Methodology matters! Funct Ecol 22:134-147 . https://doi.org/10.1111/j.1365-2435.2007.01339.x

Lázari PR De, Santos-Filho M dos, Canale GR, Graipel ME (2013) Flood-mediated use of habitat by 
large and midsized mammals in the Brazilian Pantanal. Biota Neotrop 13:70-75 . https://doi.org/10.1590/S1676-06032013000200007

Lázaro WL, Oliveira-Júnior ES, da Silva CJ, Castrillon SKI, Muniz CC (2020) Climate change reflected in one of the largest wetlands in the world: An overview of the Northern Pantanal water regime. Acta Limnol Bras 32:1-8 . https://doi.org/10.1590/s2179-975x7619

Leal CG, Lennox GD, Ferraz SFB, Ferreira J, Gardner TA, Thomson JR, Berenguer E, Lees AC, Hughes RM, MacNally R, Aragão LEOC, Brito JG de, Castello L, Garrett RD, Hamada N, Juen L, Leitão RP, Louzada J, Morello TF, Moura NG, Nessimian JL, Oliveira-Junior JMB, Oliveira VHF, Oliveira VC de, Parry L, Pompeu PS, Solar RRC, Zuanon J, Barlow J (2020) Integrated terrestrialfreshwater planning doubles conservation of tropical aquatic species. Science (80- ) 121:117-121

Libonati R, Belém LBC, Rodrigues JA, Santos FLM, Sena CAP, Pinto MM, Carvalho IA (2020) Sistema ALARMES - Alerta de área queimada Pantanal, situação atual - terceira semana de novembro de 2020. Rio de Janeiro

Liu X, Wang H (2018) Effects of loss of lateral hydrological connectivity on fish functional diversity. Conserv Biol 32:1336-1345 . https://doi.org/10.1111/cobi.13142

Lorenzón RE, Ronchi-Virgolini AL, Blake JG (2020) Wetland dependency drives temporal turnover of bird species between high- and low-water years in floodplain wetlands of the Paraná River. Ecohydrology 13: . https://doi.org/10.1002/eco.2179

Lovas-Kiss Á, Vincze O, Kleyheeg E, Sramkó G, Laczkó L, Fekete R, Molnár V. A, Green AJ (2020) Seed mass, hardness, and phylogeny explain the potential for endozoochory by granivorous waterbirds. Ecol Evol 10:1413-1424 . https://doi.org/10.1002/ece3.5997

Luck GW, Carter A, Smallbone L (2013) Changes in Bird Functional Diversity across Multiple Land Uses: Interpretations of Functional Redundancy Depend on Functional Group Identity. PLoS One 8: . https://doi.org/10.1371/journal.pone.0063671

Luck GW, Lavorel S, Mcintyre S, Lumb K (2012) Improving the application of vertebrate trait-based frameworks to the study of ecosystem services. J Anim Ecol 81:1065-1076 . https://doi.org/10.1111/j.1365-2656.2012.01974.x

Mason NWH, Mouillot D, Lee WG, Wilson JB (2005) Functional richness, functional evenness and functional divergence: The primary components of functional diversity. Oikos 111:112-118 . https://doi.org/10.1111/j.0030-1299.2005.13886.x

Matuoka MA, Benchimol M, Carlos Morante-Filho J, Maísa Matuoka CA (2020) Tropical forest loss drives divergent patterns in functional diversity of forest and non-forest birds. Biotropica 00:1-11 . https://doi.org/10.1111/btp.12795

Mega ER (2020) 'Apocalyptic’ fires tropical wetland. Nature 586:20-21

Miranda CS, Gamarra RM, Mioto CL, Silva NM, Conceição Filho AP, Pott A (2018) Analysis of the landscape complexity and heterogeneity of the Pantanal wetland. Brazilian J Biol 78:318-327 . https://doi.org/10.1590/1519-6984.08816

Mitsch WJ, Bernal B, Hernandez ME (2015) Ecosystem services of wetlands. Int J Biodivers Sci Ecosyst Serv Manag 11:1-4 . https://doi.org/10.1080/21513732.2015.1006250

Mouchet MA, Villéger S, Mason NWH, Mouillot D (2010) Functional diversity measures: An overview 
of their redundancy and their ability to discriminate community assembly rules. Funct Ecol 24:867876 . https://doi.org/10.1111/j.1365-2435.2010.01695.x

Mouillot D, Graham NAJ, Villéger S, Mason NWH, Bellwood DR (2013) A functional approach reveals

community responses to disturbances. Trends Ecol Evol 28:167-177 . https://doi.org/10.1016/j.tree.2012.10.004

Norris K, Terry A, Hansford JP, Turvey ST (2020) Biodiversity Conservation and the Earth System : Mind the Gap. Trends Ecol Evol xx:1-8 . https://doi.org/10.1016/j.tree.2020.06.010

Oliveira MD de, Calheiros DF, Padovani CR (2013) Mapeamento e descrição das áreas de ocorrência dos eventos de decoada no Pantanal. Embrapa Pantanal, Corumbá

Olivo-Neto AM, da Silva CJ, Ikeda-Castrillon SK, Lazaro WL, Damasceno-junior GA, Gris D, Pereira TDC, Sander NL (2020) Spatial distribution of single specie dominant forests of. Trop Ecol. https://doi.org/10.1007/s42965-020-00081-x

Pansonato A, Mott T, Strüssmann C (2011) Anuran amphibians' diversity in a northwestern area of the Brazilian Pantanal. Biota Neotrop 11:77-86 . https://doi.org/10.1590/s1676-06032011000400008

Penha J, Landeiro VL, Ortega JCG, Mateus L (2017) Interchange between flooding and drying, and spatial connectivity control the fish metacommunity structure in lakes of the Pantanal wetland. Hydrobiologia 797:115-126 . https://doi.org/10.1007/s10750-017-3164-9

Petchey OL, Gaston KJ (2006) Functional diversity: Back to basics and looking forward. Ecol Lett 9:741-758 . https://doi.org/10.1111/j.1461-0248.2006.00924.X

Piacentini V de Q, Aleixo A, Agne CE, Maurício GN, Pacheco JF, Bravo GA, Brito GRR, Naka LN, Olmos F, Posso S, Silveira LF, Betini GS, Carrano E, Franz I, Lees AC, Lima LM, Pioli D, Schunck F, Amaral FR do, Bencke GA, Cohn-Haft M, Figueiredo LFA, Straube FC, Cesari E (2015) Annotated checklist of the birds of Brazil by the Brazilian Ornithological Records Committee / Lista comentada das aves do Brasil pelo Comitê Brasileiro de Registros Ornitológicos. Rev Bras Ornitol 23:91-298 . https://doi.org/urn:lsid:zoobank.org:pub:30856542-FFD1-44CAB249-9F321CD4CF4C

Piatti L, Rosauer DF, de C. Nogueira C, Strussmann C, Ferreira VL, Martins M (2019) Snake diversity in floodplains of central South America: Is flood pulse the principal driver? Acta Oecologica 97:3441 . https://doi.org/10.1016/j.actao.2019.04.003

Pinho JB, Aragona M, Hakamada KYP, Marini MA (2017) Migration patterns and seasonal forest use by birds in the Brazilian Pantanal. Bird Conserv Int 27:371-387 . https://doi.org/10.1017/s0959270916000290

R Development Core Team (2019) R: A language and environment for statistical computing. R Foundation for Statistical Computing, Vienna, Austria, http://www.R-project.org/.

Ramsar Convention (1971). Convention on Wetlands of International Importance Especially as Waterfowl Habitat. Present text of the Convention on Wetlands, Iran, 2 February 1971. https://www.ramsar.org/document/present-text-of-the-convention-on-wetlands. Accessed 17 February 2021

Reid AJ, Carlson AK, Creed IF, Eliason EJ, Gell PA, Johnson PTJ, Kidd KA, MacCormack TJ, Olden JD, Ormerod SJ, Smol JP, Taylor WW, Tockner K, Vermaire JC, Dudgeon D, Cooke SJ (2019) 
Emerging threats and persistent conservation challenges for freshwater biodiversity. Biol Rev 94:849-873 . https://doi.org/10.1111/brv.12480

Sekercioglu CH (2006) Increasing awareness of avian ecological function. Trends Ecol Evol 21:464-471 . https://doi.org/10.1016/j.tree.2006.05.007

Sekercioglu CH (2012) Bird functional diversity and ecosystem services in tropical forests, agroforests and agricultural areas. J Ornithol 153:153-161 . https://doi.org/10.1007/s10336-012-0869-4

Sekercioglu CH, Daily GC, Ehrlich PR (2004) Ecosystem consequences of bird declines. Proc Natl Acad Sci U S A 101:18042-18047 . https://doi.org/10.1073/pnas.0408049101

Setubal RB, Petry AC, Bonecker CC, Martins T, Nova CC, Figueiredo-Barros MP, Bozelli RL (2020) Biotic factors determine ecosystem processes in environments with different hydrological regimes. Freshw Biol 65:1376-1391 . https://doi.org/10.1111/fwb.13506

Sherry TW, Kent CM, Sánchez N V, Şekercioğlu ÇH (2020) Insectivorous birds in the Neotropics : Ecological radiations, specialization, and coexistence in species-rich communities Insectivorous birds in the Neotropics Insectivorous birds in the Neotropics : Ecological radiations, specialization, and coexist. Auk Ornithol Adv 137:1-27 . https://doi.org/10.1093/auk/ukaa049

Silva GG, Green AJ, Hoffman P, Weber V, Stenert C, Leonardo ÁL (2020) Seed dispersal by neotropical waterfowl depends on bird species and seasonality. Freshw Biol 1-11 . https://doi.org/10.1111/fwb.13615

Somenzari M, Amaral PP do, Cueto VR, Guaraldo ADC, Jahn AE, Lima DM, Lima PC, Lugarini C, Machado CG, Martinez J, Nascimento JLX do, Pacheco JF, Paludo D, Prestes NP, Serafini PP, Silveira LF, Sousa AEBA de, Sousa NA de, Souza MA de, Telino-Júnior WR, Whitney BM (2018) An overview of migratory birds in Brazil. Pap Avulsos Zool 58:1-66 . https://doi.org/10.11606/1807-0205/2018.58.03

Stotz DF, Fitzpatrick JW, Parker III T, Moskovits DK (1996) Neotropical birds: Ecology and conservation. Chicago, USA: University of Chicago Press.

Thomas KPCS, Bueno E da R, Teixido AL, Pinho JB De (2020) Seasonality determines bird abundance, richness, and diversity among contrasting forest environments in the Northern Pantanal. Ornithology Research

Tilman D (2001) Functional Diversity. Encycl Biodivers 3:109-120 . https://doi.org/10.1016/b0-12$226865-2 / 00132-2$

Tilman D (2004) Niche tradeoffs, neutrality, and community structure: A stochastic theory of resource competition, invasion, and community assembly. Proc Natl Acad Sci U S A 101:10854-10861 . https://doi.org/10.1073/pnas.0403458101

Tockner K, Stanford JA (2002) Riverine flood plains: Present state and future trends. Environ Conserv 29:308-330 . https://doi.org/10.1017/S037689290200022X

Tonkin JD, Bogan MT, Bonada N, Rios-Touma B, Lytle DA (2017) Seasonality and predictability shape temporal species diversity. Ecology 98:1201-1216 . https://doi.org/10.1002/ecy.1761

Van Leeuwen CHA, Lovas-Kiss Á, Ovegård M, Green AJ (2017) Great cormorants reveal overlooked secondary dispersal of plants and invertebrates by piscivorous waterbirds. Biol Lett 13:10-14 . https://doi.org/10.1098/rsbl.2017.0406 
Veloso HP, Rangel-Filho ALT, Lima JCA (1991). Classificação da vegetação brasileira adaptada a um sistema universal. IBGE, Rio de Janeiro.

Villéger S, Mason NWH, Mouillot D (2008) New multidimensional functional diversity indices for a multifaceted framework in functional ecology. Ecology 89:2290-2301 . https://doi.org/10.1890/071206.1

Wantzen KM, Drago E, Da Silva CJ (2005) Aquatic habitats of the Upper Paraguay river-floodplainsystem and parts of the Pantanal (Brazil). Ecohydrol Hydrobiol 5:107-126 . https://doi.org/10.1364/CLEO_SI.2011.CTuM6

Whelan CJ, Wenny DG, Marquis RJ (2008) Ecosystem Services Provided by Birds. Ann N Y Acad Sci 1134:25-60 . https://doi.org/doi: 10.1196/annals.1439.003

Wickham H (2016) ggplot2: Elegant Graphics for Data Analysis. Springer-Verlag New York. https://doi.org/10.1007/978-3-319-24277-4

Wilkinson DM, Lovas-Kiss A, Callaghan DA, Green AJ (2017) Endozoochory of Large Bryophyte Fragments by Waterbirds. Cryptogam Bryol 38:223-228 . https://doi.org/10.7872/cryb/v38.iss2.2017.223

Wilman H, Belmaker J, Simpson J, de La Rosa C, Rivadeneira MM, Jetz W (2014) EltonTraits 1 . 0 : Species-level foraging attributes of the world' s birds and mammals. Ecology 95:2027

Zuur AF, Ieno EN, Walker NJ, Saveliev AA, Smith GM (2009) Mixed Effects Models and Extensions in Ecology with R 


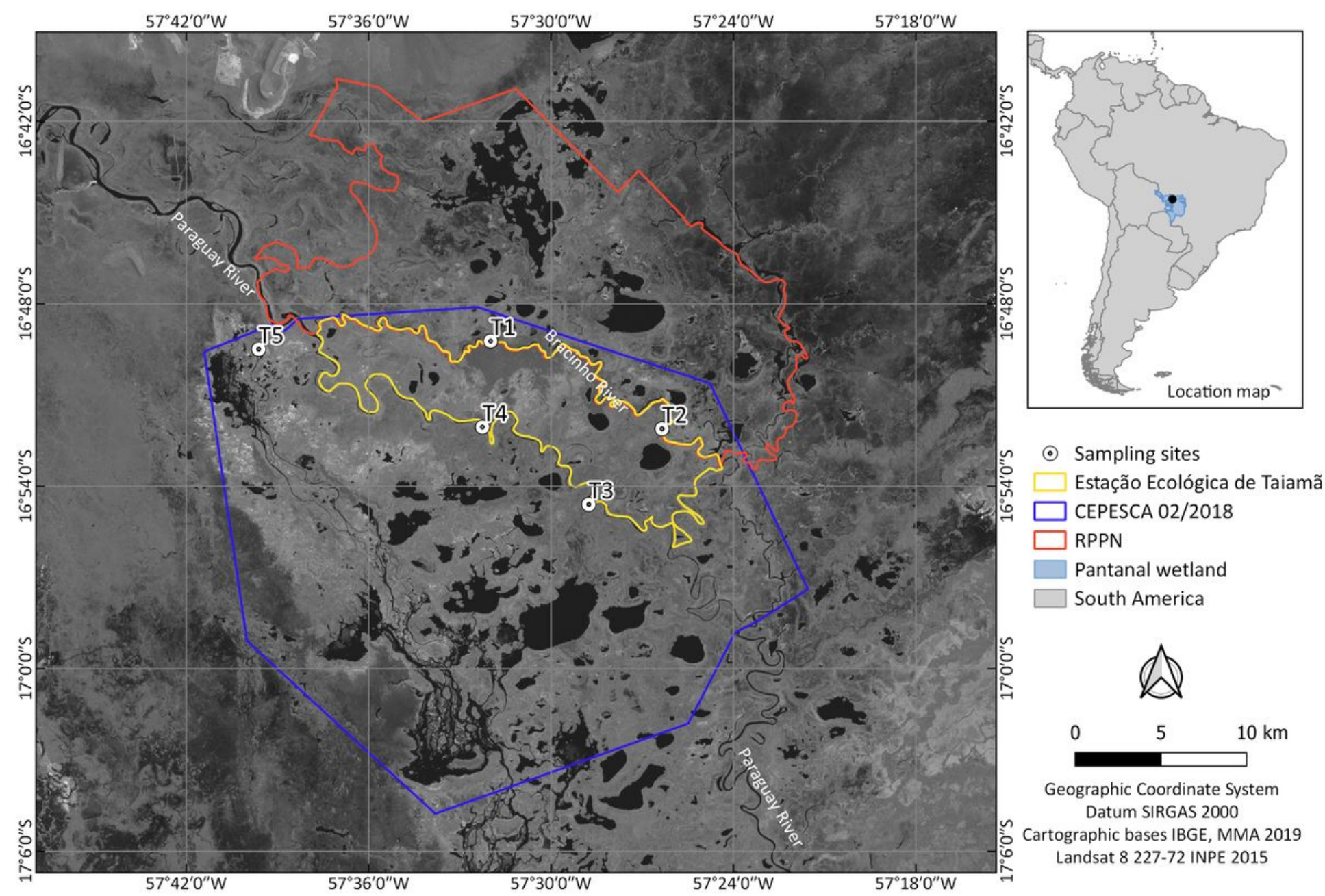

\section{Figure 1}

Location of the sampling sites in the Paraguay River floodplain, Pantanal wetland, Brazil. Note: The designations employed and the presentation of the material on this map do not imply the expression of any opinion whatsoever on the part of Research Square concerning the legal status of any country, territory, city or area or of its authorities, or concerning the delimitation of its frontiers or boundaries. This map has been provided by the authors. 


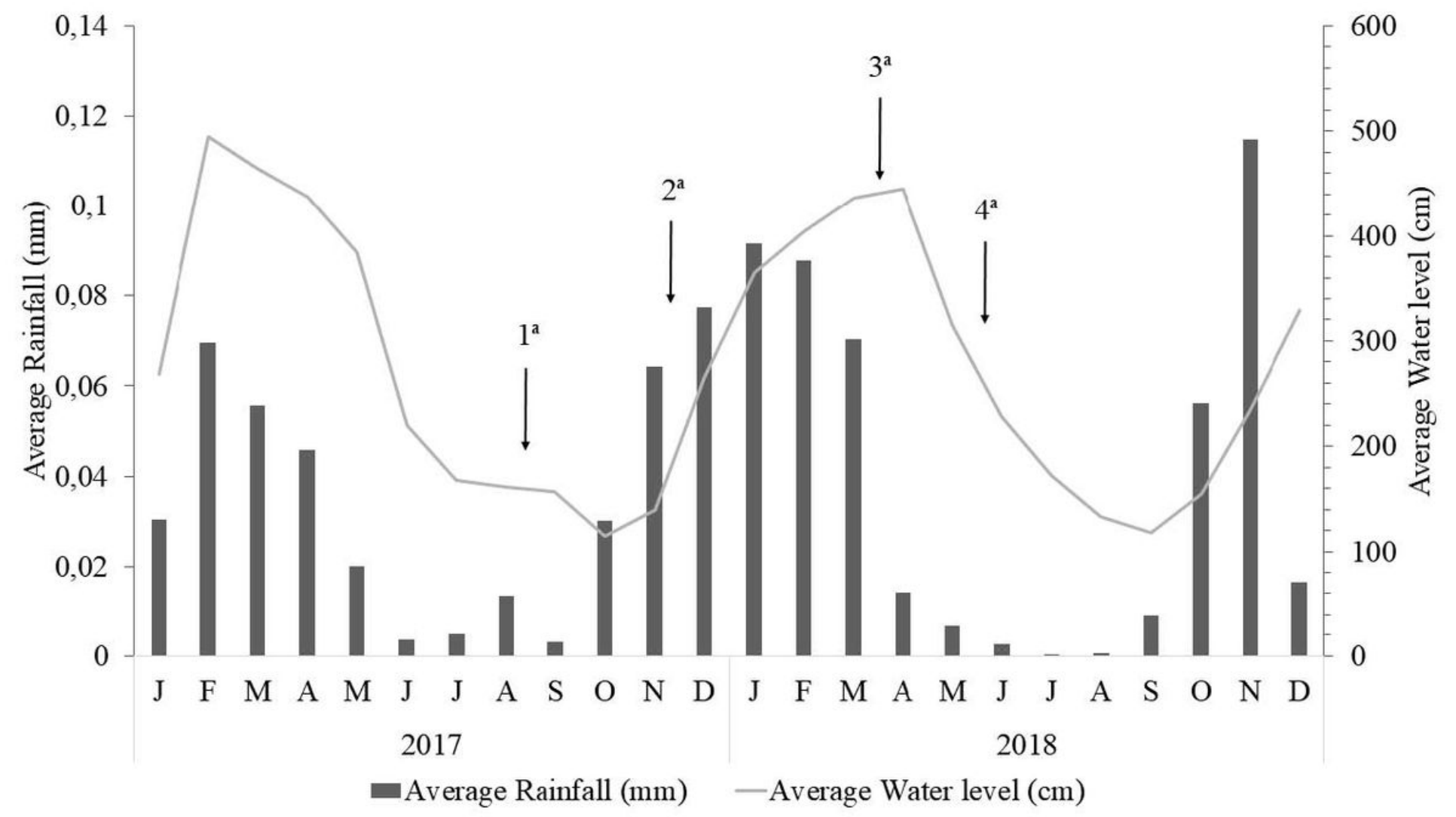

\section{Figure 2}

Hydrological cycle 2017-2018 showing average rainfall $(\mathrm{mm})$ and average water level $(\mathrm{cm})$ in the Paraguay River, Cáceres hydrological station, Paraguay watershed, Brazil. Arrows indicate the four birdmonitoring campaigns carried out during the cycle, covering the hydrological periods drought, flooding, full flood, and ebb. Source of telemetric data: Agência Nacional das Águas (2019). 

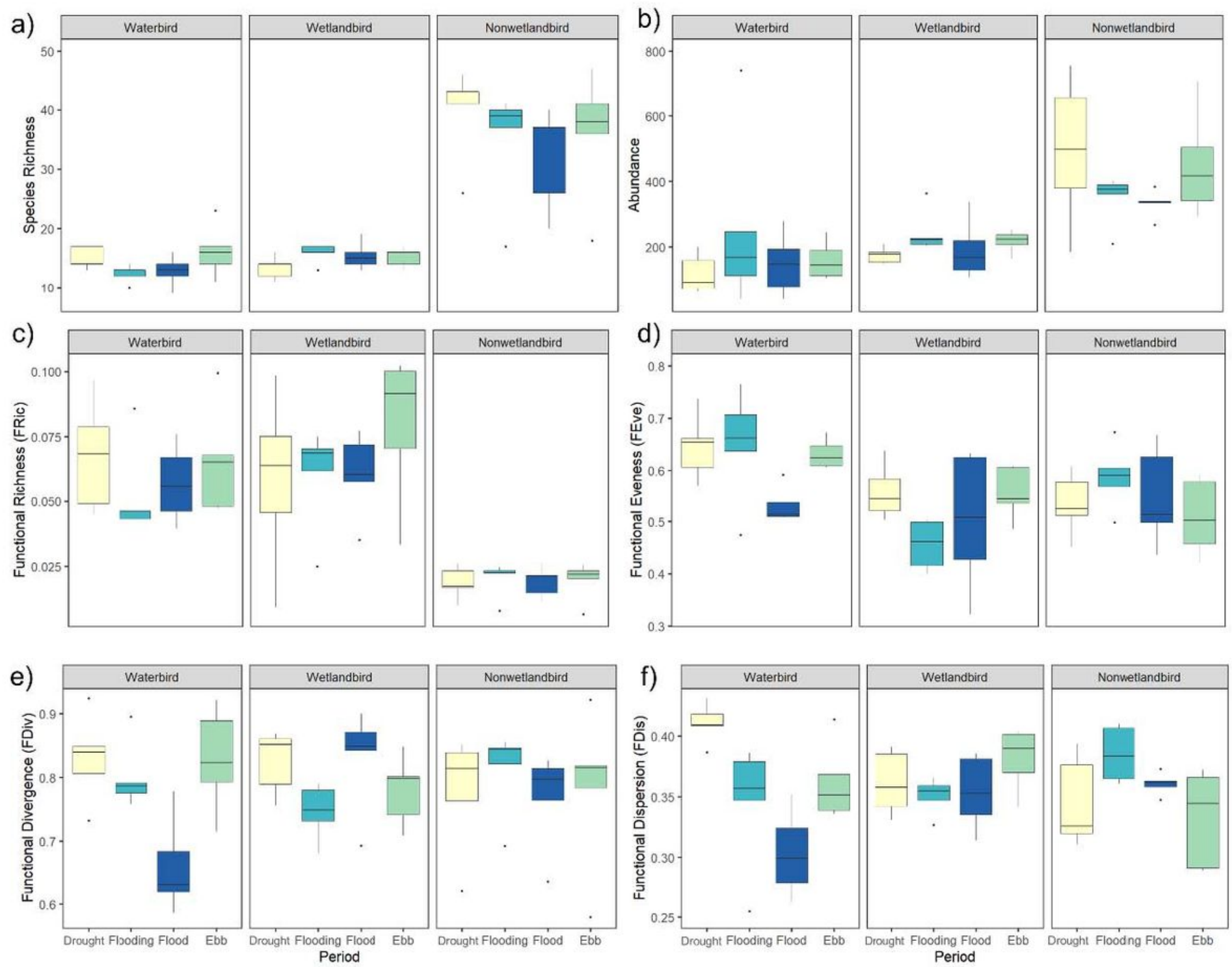

\section{Figure 3}

Variations in species richness, abundance of individuals and functional diversity measures of waterbirds, wetland birds and non-wetland birds between hydrological periods in the Paraguay River floodplain, Pantanal wetland, Brazil. Boxplots show the median values (thick centerline), quartiles (bottom and top of the boxes), maximum and minimum values (whiskers) and outliers (circles). a) Species richness; $b$ ) Abundance; c) Functional richness (FRic); d) Functional evenness (FEve); e) Functional divergence (FDiv), f) Functional dispersion (FDis). 
a) Drought

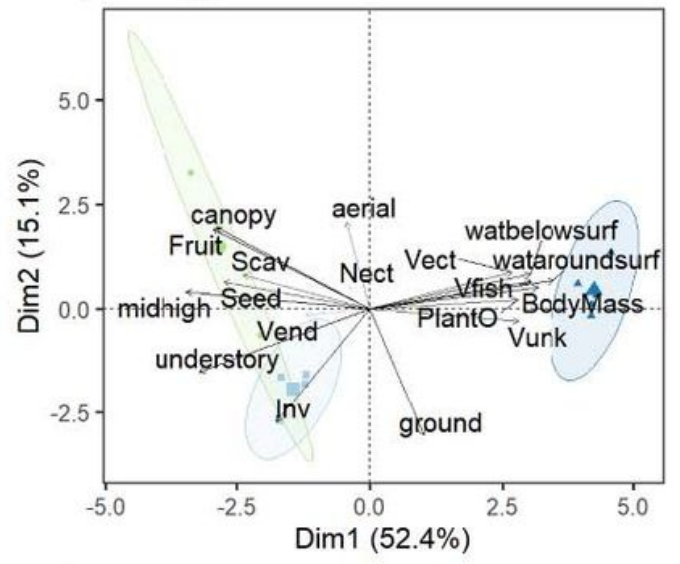

C) Full flood

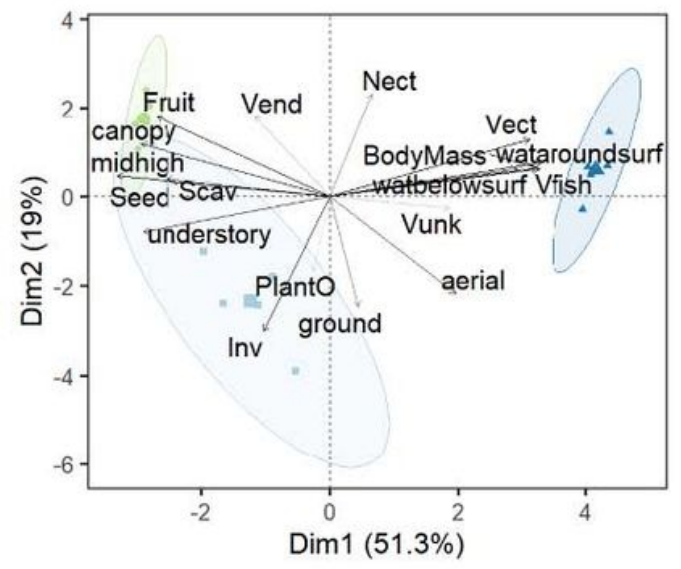

b) Flooding

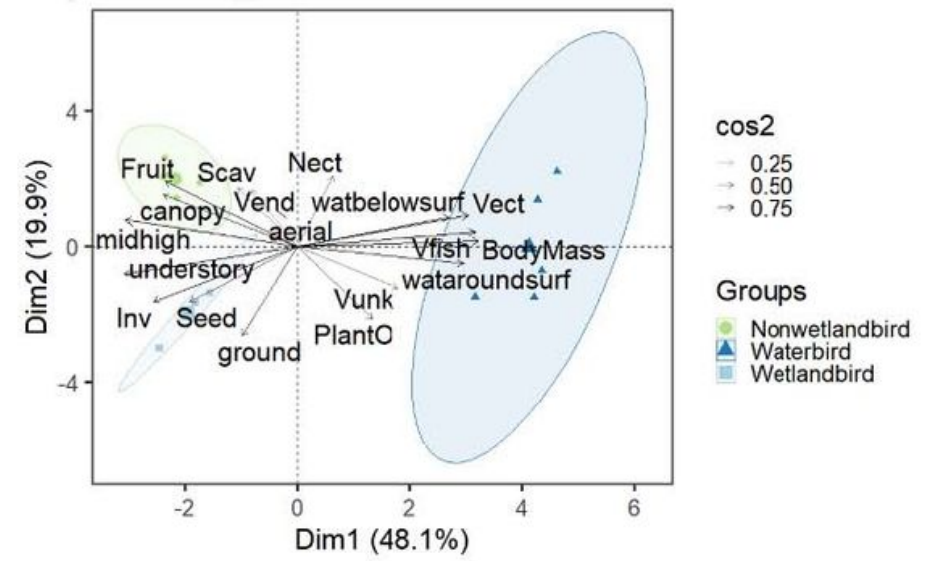

d) $\mathrm{Ebb}$

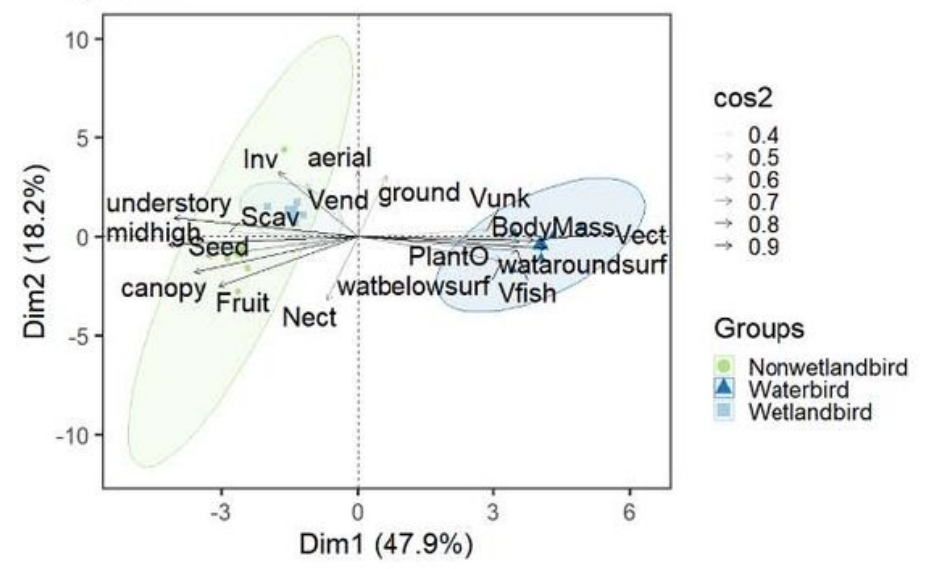

0.25

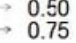

Groups

- Nonwetlandbird Wertand $\rightarrow 0.6$

$\rightarrow \infty$

Groups

Nonwetlandbird Waterbird

\section{Figure 4}

$\cos 2$

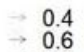

$\rightarrow 0.8$

Groups

- Nonwetlandbird

Waterbird

Wetlandbird

$\cos 2$

$\rightarrow \quad 0.50$

Groups

Nonwetlandbird Wetlandbird

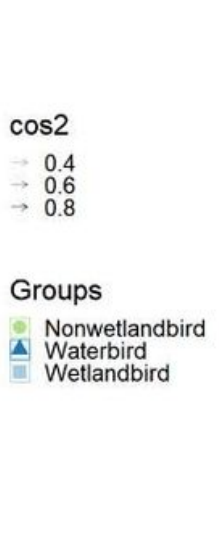

Ordination diagram of the principal components analysis (PCA) showing the variation in the set of community-weighted mean (CWM) trait value of the waterbirds, wetland birds and non-wetland birds for each hydrological period (a) Drought, b) Flooding, c) Full flood and d) Ebb) in the Paraguay River floodplain, Pantanal wetland, Brazil. 